\title{
PERBEDAAN STRAIN DAN UMUR BETINA TERHADAP JUMLAH KETURUNAN LALAT BUAH (Drosophila melanogaster Meigen)
}

\author{
Ramadhan Taufika $^{1^{\star}}$, Setyo Andi Nugroho² ${ }^{2}$ Anni Nuraisyah ${ }^{3}$ \\ $1^{*}$ Jurusan Produksi Pertanian Politeknik Negeri Jember \\ 2Jurusan Produksi Pertanian Politeknik Negeri Jember \\ ${ }^{3}$ Jurusan Produksi Pertanian Politeknik Negeri Jember \\ *Corresponding Author email: ramadhantaufika@polije.ac.id
}

\begin{tabular}{|c|c|}
\hline \multirow{5}{*}{$\begin{array}{l}\text { Diterima } \\
\text { Bulan Januari } \\
2020\end{array}$} & Abstrak \\
\hline & Telah dilakukan penelitian Perbedaan Strain dan Umur Betina Terhadap Jumlah \\
\hline & Keturunan Lalat Buah (Drospohila melanogaster Meigen) untuk mengetahui pengaruh \\
\hline & $\begin{array}{l}\text { strain dan umur betina terhadap jumlah keturunan } D \text {. melanogaster pada strain normal, } \\
\text { taxi, dan sepia. Sebanyak } 5 \text { ekor } D \text {. melanogaster }{ }^{1} \text { normal disilangkan dengan } 5 \text { ekor }\end{array}$ \\
\hline & D. melanogaster $\bigcirc$ normal, 5 ekor $D$. melanogaster $\widehat{\supset}$ taxi disilangkan dengan 5 ekor $D$. \\
\hline Diterbitkan & melanogaster $q$ taxi, 5 ekor $D$. melanogaster $\widehat{\sigma}$ sepia disilangkan dengan 5 ekor $D$. \\
\hline Bulan Februari & melanogaster q sepia. Umur betina yang disilangkan adalah 8-10 jam, $12-14$ jam, 16-18 \\
\hline 2020 & jam, 20-22 jam, dan 24-26 jam sejak menetas dari pupa. Setiap kelompok persilangan \\
\hline & diulang lima kali. Persilangan $D$. melanogaster dilakukan pada suhu $25^{\circ} \mathrm{C}$. Data dianalisis \\
\hline Keyword : D. & signifikansi $5 \%$. Berdasarkan hasil penelitian diketahui bahwa ada pengaruh strain dan \\
\hline melanogaster , & umur betina terhadap jumlah keturunan. Diketahui pula bahwa strain normal \\
\hline keturunan, st & menghasilkan jumlah keturunan terbanyak, sedangkan strain taxi menghasilkan jumlah \\
\hline umur betina & nan paling sedikit. Umur betina $20-22$ jam menghasilkan jumlah keturunan yang \\
\hline & aling banyak dan tidak berbeda nyata dengan umur betina $24-26$ jam, sedangkan umur \\
\hline & $\begin{array}{l}\text { 8-10 jam menghasilkan jumlah keturunan paling sedikit dan tidak berbeda nyata dengan } \\
\text { umur } 12-14 \text { jam. }\end{array}$ \\
\hline
\end{tabular}

\section{PENDAHULUAN}

Lalat buah (Drosophila melanogaster) diketahui telah mengalami banyak mutasi yang menghasilkan variasi genotip intraspesifik yang disebut strain. Selain dalam keadaan normal $(\mathrm{N})$ ditemukan ada beberapa strain yang merupakan hasil mutasi dan menghasilkan mutan-mutan yang berbeda dari keadaan normal. Perbedaan tersebut terutama terkait dengan warna mata, bentuk mata, dan bentuk sayap (Karmana, 2010). Beberapa jenis mutasi pada $D$. melanogaster yang terlihat dari fenotipnya adalah mutasi warna mata, bentuk mata, bentuk sayap, dan warna tubuh sehingga dikenal berbagai strain dari $D$. melanogaster antara lain $\mathrm{w}$ (white), se (sepia), eym (eyemissing), cu (curled), tx (taxi), dp (dumpy), dan vg (vestigial). Perbedaanperbedaan fenotip yang tampak tersebut disebabkan telah terjadi perubahan pada genotip dari keadaan normal. Selain memberikan dampak pada fenotip, perubahan pada genotip akan menyebabkan perubahan secara fisiologis misalnya proses reproduksi (Karmana, 2010). Mekanisme penggunaan sperma untuk pembuahan sel telur tidak selalu sama pada semua strain D. melanogaster. Selain itu, jumlah sperma yang ditransfer $D$. melanogaster jantan berkaitan dengan perbedaan strain (Fowler, 1973). Pada persilangan sesama strain (white, ebony, dan Normal) D. melanogaster terdapat perbedaan jumlah keturunan (Muliati, 2000). Hasil penelitian Karmana (2010) pada persilangan D. melanogaster sesama strain (normal, vestigial, dan taxi) terdapat perbedaan jumlah keturunan.

Terkait dengan umur seksual betina untuk kawin pada D. melanogaster diperoleh informasi yang bervariasi. D. melanogaster betina akan mencapai kedewasaan seksual pada umur 8 jam setelah keluar dari pupa (Shorrock, 1972). D. melanogaster betina mencapai kedewasaan seksual pada umur 24 jam setelah keluar dari pupa (Hartanti, 1998). D. melanogaster betina akan mencapai kedewasaan seksual setelah umur 24 jam setelah keluar dari pupa (Fowler, 1973). Sumber yang sama menyebutkan bahwa jumlah sel telur pada $D$. melanogaster antara lain dipengaruhi oleh faktor umur betina dan strain induk. Berdasarkan pernyataan Fowler (1973) bahwa ada keterkaitan antara umur betina dan strain induk dengan jumlah keturunan. Oleh karena itu, perlu dilakukan penelitian lebih lanjut untuk mengetahui perbedaan strain dan umur betina terhadap jumlah keturunan $D$. melanogaster strain Normal, taxi, dan sepia. 


\section{LANDASAN TEORI}

Terdapat beberapa pendapat mengenai waktu kedewasaan seksual individu betina $D$. melanogaster. Shorrock (1972) menyatakan bahwa D. melanogaster betina akan mencapai kedewasaan seksual pada usia 8 jam setelah menetas dari pupa. Hartanti (1998) menyebutkan bahwa $D$. melanogaster betina mencapai kedewasaan seksual pada waktu berumur 24 jam setelah keluar dari pupa. Fowler (1973) menambahkan bahwa $D$. melanogaster betina yang baru menetas biasanya belum siap kawin dengan $D$. melanogaster jantan dan akan mencapai kedewasaan seksual setelah umur 24 jam setelah keluar dari pupa.

Pada saat $D$. melanogaster betina berumur 24 jam maka individu betina tersebut akan bersifat reseptif yaitu suatu keadaan pada individu betina yang dapat menerima individu jantan untuk melakukan perkawinan pertama kali (Kiptiyah, 1998). Menurut Hartanti (1998) menyatakan bahwa jika individu betina melakukan penolakan kawin dengan individu jantan, hal ini dapat dihubungkan karena belum tercapainya kematangan ovarium dan belum terjadi pertambahan hormon kelamin (Hartanti, 1998). Hal ini diperkuat dari hasil penelitian Karmana (2010) yang menyimpulkan pada persilangan $D$. melanogaster sesama strain yaitu Normal, vestigial, dan taxi dengan umur betina 8 jam, 12 jam, 16 jam, 20 jam, dan 24 jam terdapat perbedaan jumlah keturunan. Umur betina 16 jam, 20 jam, dan 24 jam memberikan pengaruh yang cukup tinggi terhadap jumlah keturunan, sedangkan umur 8 jam dan 12 jam memberikan pengaruh yang kecil terhadap jumlah keturunan.

Sel telur dihasilkan oleh lalat betina melalui proses oogenesis. Waktu dimulainya oogenesis pada D. melanogaster betina adalah saat larva akhir. Oogenesis juga masih berlangsung pada saat imago (Muliati, 2000). Lebih lanjut disebutkan bahwa oogenesis pada kebanyakan anggota kelas insecta terjadi pada larva instar akhir, saat pupa, dan pada imago.

D. melanogaster mengalami tahap oogenesis yang khas dan singkat, yaitu berlangsung selama 24 jam. Sel telur dibentuk dalam tabung (ovariola) yang terbagi menjadi ruangan-ruangan oleh dinding transversal. Sel-sel yang menyusun dinding ovariola dan mengelilingi sel telur nantinya disebut sel-sel folikel yang analog dengan sel-sel folikel pada vertebrata. Pada masing-masing ruangan dalam ovariola terdapat satu sel germ primordial disebut oogonium. Kemudian oogonium mengalami empat kali pembelahan mitosis menghasilkan 16 sel yang dihubungkan oleh jembatan sitoplasmik yang disebut fusome. Dua dari 16 sel dihubungkan dengan empat sel saudara, satu dari dua sel tersebut akan berkembang menjadi oosit sedangkan 15 sel lainnya berkembang menjadi sel pengasuh (nurse cell) (Muller,1997).
Pada perkembangannya oosit bersifat diploid yang selanjutnya akan menjadi haploid setelah pembelahan meiosis, sedangkan sel pengasuh akan menjadi poliploidi karena terjadi replikasi DNA dengan cepat. Sel pengasuh menyediakan ribosom dan mRNA dalam bentuk partikel ribonukleoprotein (RNP) yang akan dipindahkanmenuju oosit melalui fusome yang berfungsi untuk perkembangan telur. Pada tahap akhir oogenesis, sel-sel folikel membantu memelihara oosit. Sel-sel folikel membantu menyediakan yolk telur yang disintesis dari vitellogenin dan fosfovitin. Vitellogenin dan fosfovitin berada di dalam hemolimfa yang dikumpulkan oleh sel-sel folikel dan dipindahkan ke oosit untuk membentuk asam amino, fosfat, dan energi. Selain itu fungsi sel-sel folikel yaitu mensekresikan korion (Muller,1997).Ovum fungsional akan diovulasikan ke dalam oviduk yang disebabkan oleh kontraksi otot-otot oviduk dan desakan ovum lainnya yang telah mengalami pematangan. Jika ovum telah fungsional maka dapat dikatakan individu betina telah mencapai kedewasaan seksual dan siap menerima induk jantan untuk melakukan perkawinan (Shorrock, 1972).

\section{METODE PENELITIAN}

\section{Alat dan Bahan}

Alat-alat yang digunakan meliputi mikroskop stereo Olympus SZ51, kamera digital Nikon Coolpix S1000pj, jangka sorong, blender, cawan petri, botol selai diameter $4,56 \mathrm{~cm}$, selang plastik diameter $0,02 \mathrm{~cm}$, kapas, hand counter, petridish, kuas lukis nomor 2, kertas label, botol/plastik ampul, busa penyumbat diameter $6 \mathrm{~cm}$, silet/cutter, timbangan bahan kapasitas 100 gram, pisau, termometer ruang, batang pengaduk. Bahanbahan yang digunakan yaitu eter, $D$. melanogaster strain Normal, taxi, sepia jantan dan betina yang diperoleh dari biakan di Laboratorium Biologi Dasar Jurusan Biologi Fakultas Matematika dan Ilmu Pengetahuan Alam Universitas Jember. Media untuk pertumbuhan D. melanogaster meliputi pisang ambon, gula merah nonsulfit dari industri rumahan gula merah di Pasirian, agar agar (merk swallow globe), air, methyl paraben (Merck), dan yeast (fermipan).

\section{Rancangan Penelitian}

Rancangan Penelitian ini menggunakan desain Rancangan Acak Lengkap (RAL) dengan tiga kelompok persilangan yang berbeda yaitu $\widehat{\sigma}$ normal $(n)><q$ normal $(n), \partial \operatorname{taxi}(t x)><q$ taxi $(t x)$, $\widehat{\jmath}$ sepia $(s e)><$ sepia (se). Setiap tipe persilangan dilakukan untuk umur betina 8-10 jam, 12-14 jam, 16-18 jam, 20-22 jam, dan 24-26 jam serta masingmasing dengan lima kali ulangan (Karmana, 2010). Pengamatan dilakukan dengan menghitung jumlah keturunan untuk semua jenis persilangan dan 
dilakukan setiap hari mulai dari kemunculan imago pertama sampai hari kesepuluh.

\section{Pembuatan Medium}

Cara pembuatan medium adalah sebagai berikut: pisang ditambah dengan air, diblender sampai bahan-bahan tersebut tercampur rata dan halus. Agar-agar dan gula merah dicampur dengan air kemudian dididihkan. Pisang yang sudah diblender dimasukkan dalam agar-agar dan gula merah yang sudah mendidih, diaduk sampai rata kemudian didiamkan kurang lebih selama 10 menit (sampai pisang matang) dan didinginkan kurang lebih selama 20 menit kemudian diberi ragi yang sudah dilarutkan dalam air dan dicampur dengan sorbic acid (zat pencegah jamur). Adonan dituang kedalam botol dan diberi kertas pupasi, selanjutnya botol ditutup dengan busa (Oktarianti dan Widajati, 2011).

\section{Isolasi Induk Betina Virgin}

Isolasi Induk Betina Virgin Disiapkan botol yang berisi medium. Dimasukkan 5 ekor sesama $D$. melanogaster $\widehat{o} n$ dengan 5 ekor $D$. melanogaster O $n, 5$ ekor $D$. melanogaster $\lesssim$ tx dengan 5 ekor $D$. melanogaster + $t x, 5$ ekor D. melanogaster ô se dengan 5 ekor D. melanogaster $q$ se dalam botol yang berbeda. Setelah muncul pupa, induk dipindahkan ke dalam botol lain untuk peremajaan. Untuk memperoleh betina virgin maka dilakukan isolasi masing-masing pupa dalam ampul yang berbeda.

\section{Teknik Persilangan}

Disiapkan masing-masing botol perlakuan. 5 ekor D. melanogaster $\widehat{T} N$ dikawinkan dengan 5 ekor D. melanogaster $q N, 5$ ekor $D$. melanogaster ot $x$ dikawinkan dengan 5 ekor $D$. melanogaster $q$ tx, 5 ekor D. melanogaster $\widehat{\jmath}$ se dikawinkan dengan 5 ekor D. melanogaster 9 se. Umur betina yang dikawinkan adalah 8-10 jam, 12-14 jam, 16-18 jam, 20-22 jam, dan 2426 jam sejak menetas dari pupa dengan masing-masing kelompok persilangan dilakukan lima kali pengulangan. Persilangan $D$. melanogaster dilakukan pada suhu ruangan $25^{\circ} \mathrm{C}$.

\section{Cara Penghitungan Jumlah Keturunan Generasi Pertama (F1)}

Jumlah keturunan dihitung sejak menetasnya imago. Selanjutnya dihitung jumlah keturunan F1 jantan dan betina untuk hari pertama sampai hari kesepuluh.

\section{Analisis Data}

Data yang diperoleh dianalisis dengan anava faktorial, jika hasilnya bermakna $\mathrm{p} \leq 0,05$ dilanjutkan dengan uji Beda nyata Terkecil (BNT) pada taraf signifikansi 5\% [7]

\section{HASIL DAN PEMBAHASAN}

Rata-rata jumlah keturunan generasi pertama (F1) persilangan D. melanogaster sesama strain normal (n), taxi (tx), dan sepia (se) dengan umur betina 8-10 jam, 12-14 jam, 16-18 jam, 20-22 jam, dan 24-26 jam pada suhu $25^{\circ} \mathrm{C}$ dapat dilihat pada tabel 1 .

Tabel 1. Rata-rata jumlah keturunan F1 pada ketiga persilangan.

\begin{tabular}{|c|c|c|c|c|}
\hline \multirow{2}{*}{ Umur Betina } & \multicolumn{3}{|c|}{ Persilangan } & \multirow{2}{*}{ Rata-rata } \\
\hline & $\delta \mathrm{n}><\mathrm{n}$ & $\hat{\partial} \underline{\mathrm{tx}}><q \underline{\mathrm{t} x}$ & $\hat{\delta} \mathrm{se}><q \mathrm{se}$ & \\
\hline 8-10 jam & $407,8 \pm 17,10$ & $378,8 \pm 9,98$ & $385,4 \pm 16,47$ & $390,6 \pm 18,83^{4}$ \\
\hline 12-14 jam & $438,6 \pm 22,03$ & $387,6 \pm 12,01$ & $405,6 \pm 14,74$ & $410,6 \pm 26,83^{\mathrm{a}}$ \\
\hline 16-18 jam & $519,8 \pm 46,66$ & $405,6 \pm 9,66$ & $437,6 \pm 7,44$ & $454,33 \pm 56,07$ \\
\hline 20-22 jam & $568,2 \pm 62,38$ & $429,6 \pm 6,80$ & $482,8 \pm 40,49$ & $493,53 \pm 71,31^{\circ}$ \\
\hline 24-26 jam & $548,6 \pm 50,64$ & $417,4 \pm 5,89$ & $465,4 \pm 28,67$ & $477,13 \pm 64,23 c$ \\
\hline Rata-rata & $496,6 \pm 75,21^{2}$ & $403,80 \pm 20,80^{b}$ & $435,36 \pm 43,16^{\mathrm{c}}$ & \\
\hline
\end{tabular}

Pada tabel 1 tampak adanya variasi ratarata jumlah keturunan yang diperoleh dari persilangan sesama strain $N$, $t x$, dan se dengan menggunakan umur betina 8-10 jam, 12-14 jam, 1618 jam, 20-22 jam, dan 24-26 jam. Rata-rata jumlah keturunan pada persilangan sesama strain $n$ dengan umur betina 8-10 jam, 12-14, 16-18 jam, 20-22 jam, dan 24-26 jam secara berturut-turut adalah 407,8 ekor; 438,6 ekor; 519,8 ekor; 568,2 ekor; dan 548,6 ekor. Untuk rata-rata jumlah keturunan pada persilangan sesama strain $t x$ dengan umur betina 810 jam, 12-14 jam, 16-18 jam, 20-22 jam, dan 24-26 jam secara berturut-turut adalah 378,8 ekor; 387,6 ekor; 405,6 ekor; 429,6 ekor dan 417,4 ekor. Untuk rata-rata jumlah keturunan pada persilangan sesama strain se dengan umur betina 8-10 jam, 12-14 jam, 16-18 jam, 20-22 jam, dan 24-26 jam secara berturutturut adalah 385,4 ekor; 405,6 ekor; 437,6 ekor; 482,8 ekor dan 465,4 ekor. Hasil analisis statistik menunjukkan bahwa perbedaan strain berpengaruh nyata terhadap jumlah keturunan $(\mathrm{P}=0,00)<0,05$ pada taraf $5 \%$.

Hasil uji lanjut dengan BNT (Beda Nyata Terkecil) taraf 5\% menunjukkan bahwa persilangan sesama strain $N$ berbeda nyata dengan persilangan sesama $t x$ dan strain $s e$, persilangan sesama strain $t x$ berbeda nyata dengan persilangan sesama strain $n$ dan strain se, dan persilangan sesama strain se berbeda nyata dengan persilangan sesama strain $N$ dan strain $t x$. Perbedaan rata-rata jumlah keturunan pada persilangan sesama strain $n, t x$ dan, se. diduga bahwa $D$. melanogaster strain normal (wild type) yang tidak mengalami mutasi memiliki pengaruh yang lebih baik terhadap jumlah keturunan dibandingkan dengan strain $t x$ dan strain se karena mutasi yang terjadi pada strain tersebut relatif kurang adaptif dibandingkan dengan strain $\mathrm{N}$ yang memang lebih adaptif dengan lingkungan. Mutasi 
memang dapat menghasilkan mutan yang adaptif tetapi dapat juga menghasilkan mutan yang kurang adaptif karena mutasi terjadi secara, 1992) acak dan tidak terarah (Corebima, 1992).

Penurunan ratarata jumlah keturunan yang diperoleh pada persilangan sesama strain $t x$ sebesar $7 \%$ dan strain se sebesar 4,6\% dapat diduga bahwa viabilitas strain $t x$ dan se rendah. Sel telur $D$. melanogaster mutan lebih rentan mengalami kerusakan dibandingkan dengan sel telur $D$. melanogaster normal (Belloni et al., 2002). Sel telur betina $D$. melanogaster mutan sewaktu-waktu dapat mengalami kerusakan sebelum terjadi fertilisasi. Selain itu Fowler (1973) menyatakan bahwa jumlah sel telur pada D. melanogaster salah satunya dipengaruhi oleh strain induk. Hal ini dapat dijelaskan bahwa strain $t x$ dan se yang telah bermutasi tentunya telah berbeda genotipnya dengan strain $N$, sehingga mempengaruhi jumlah keturunan.

Selain itu perbedaan rata-rata jumlah keturunan dari ketiga persilangan sesama strain $N$, $t x$, dan se terkait dengan aspek mutasi pada $D$. melanogaster. Aspek mutasi pada sayap berhubungan dengan keberhasilan kawin $D$. melanogaster (Indayati, 1999). Pada persilangan sesama strain $n, v g$, dan $t x$ diperoleh jumlah keturunan paling sedikit adalah strain $v g$ dan $t x$ yang kedua strain tersebut mengalami mutasi pada aspek sayap (Karmana, 2010).

Salah satu tahap perkawinan $D$. melanogaster adalah singing. Pada tahap singing, D. melanogaster jantan mengangkat sayap membentuk sudut $90^{\circ}$ dan menghasilkan suara khas sehingga $D$. melanogaster betina tertarik untuk kopulasi dan menstimulasi D. melanogaster betina untuk mensekresikan hormon kelamin (hormon volatil) yang penting pada tahap kopulasi [10]. Hal ini yang menyebabkan jumlah keturunan pada persilangan sesama strain $t x$ yang mengalami aspek mutasi pada sayap lebih sedikit dari persilangan sesama strain $N$ dengan sesama strain se yang mengalami mutasi pada aspek mata. Mutasi pada aspek sayap sangat berpengaruh pada keberhasilan kawin D. melanogaster .

Faktor lain yang diduga menyebabkan penurunan jumlah keturunan pada persilangan sesama strain $t x$ dan strain se adalah penggunaan sperma oleh individu betina. Sperma pada individu betina disimpan dalam reseptakulum seminalis dan spermateka yang kemudian digunakan untuk membuahi sel telur (Sirot et al., 2009). Pada D. melanogaster strain $N$, sperma yang tersimpan dalam reseptakulum seminalis digunakan untuk fertilisasi lebih dulu dari pada sperma yang tersimpan di spermateka (Karmana, 2010). Mekanisme ini terjadi karena posisi bagian proksimal reseptakulum seminalis terbuka langsung ke oviduk di atas uterus (Sirot et al., 2009). Akan tetapi Fowler (19730 menyatakan bahwa penggunaan sperma pada $D$. melanogaster tidak semuanya sama menggunakan sperma yang ada pada reseptakulum seminalis terlebih dulu kemudian sperma yang ada di spermateka, tetapi ada perbedaan pada berbagai strain. Lebih lanjut disebutkan bahwa kuantitas sperma yang ditransfer oleh individu jantan berhubungan dengan kuantitas sekresi kelenjar asesoris pada waktu perkawinan. Semakin besar kuantitas sekresi kelenjar asesoris maka jumlah sperma yang ditransfer akan bertambah banyak, sedangkan semakin rendah kuantitas sekresi kelenjar asesoris maka jumlah sperma yang ditransfer akan menurun. Kuantitas sekresi kelenjar asesoris pada D. melanogaster jantan tidak sama pada setiap strain (Muliati, 2000). Organ reproduksi $D$. melanogaster betina dapat dilihat pada gambar 1 .

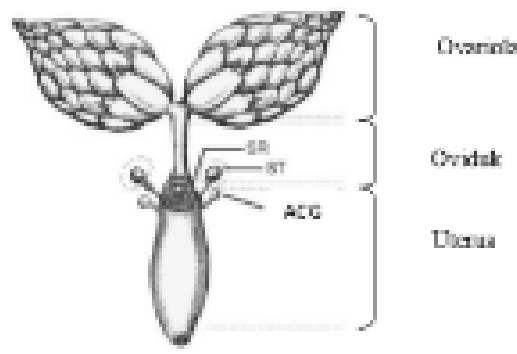

Gambar 1. Organ reproduksi D. melanogaster betina. SR merupakan reseptakulum seminalis, ST merupakan spermateka, dan ACG merupakan kelenjar asesoris (sumber: Sirot et al., 2009).

Terkait dengan jenis kelamin keturunan $D$. melanogaster, Campbell et al., (2002) menyatakan bahwa penentuan jenis kelamin keturunan merupakan masalah kemungkinan, dengan peluang keturunan jantan dibanding betina adalah 50-50. Menurut Corebima (1997) penentuan jenis kelamin (ekspresi kelamin) ditentukan oleh gen. Gen yang bertanggung jawab atas penentuan jenis kelamin makhluk hidup tidak hanya satu pasang tetapi banyak pasangan gen. Menurut Corebima (2003) menyatakan bahwa $D$. melanogaster jantan memiliki kromosom kelamin XY, sedangkan $D$. melanogaster betina memiliki kromosom kelamin XX. Dalam hubungan ini, individu betina $D$. melanogaster mewarisi satu kromosom X dari induk jantan dan satu kromosom $\mathrm{X}$ lainnya dari induk betina, sedangkan individu jantan $D$. melanogaster mewarisi satu kromosom $\mathrm{X}$ dari induk betina dan satu kromosom Y dari induk jantan. Metode penentuan jenis kelamin pada D . melanogaster dapat dilihat pada gambar 2 . 


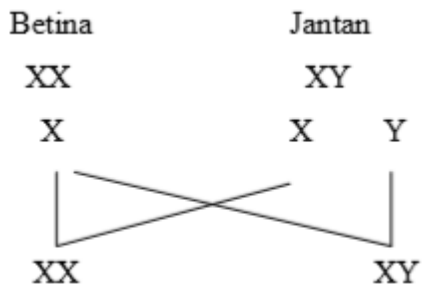

Gambar 4.2 Metode XY Pada Penentuan Jenis Kelamin (Sumber: Stansfield, 1991)

Namun jika dilihat dari hasil yang diperoleh, persilangan D. melanogaster sesama strain $N$, $t x$, dan, se memperlihatkan bahwa jenis kelamin keturunan yang paling banyak adalah betina. Hal ini diduga disebabkan oleh beberapa faktor antara lain: viabilitas lalat jantan yang rendah, segregation distortion dan karakteristik spermatozoa. Menurut Wong et al., (2012) menyatakan bahwa individu jantan pada beberapa spesies mempunyai viabilitas yang lebih rendah bila dibandingkan dengan individu betina pada semua umur. Lebih lanjut Haerty et al., (2007) menyatakan bahwa kematian zigot dapat disebabkan oleh adanya Helical mycoplasma. Helical mycoplasma merupakan infeksi yang disebabkan oleh bakteri dan virus. Infeksi mikroorganisme tersebut dapat mempengaruhi materi genetik pada $D$. melanogaster.

Pada kejadian segregation distortion (penyimpangan pemisahan) yang merupakan adanya gangguan pada pemisahan gamet saat gametogenesis menyebabkan individu jantan $D$. melanogaster akan memproduksi lebih banyak gamet yang membawa kromosom $\mathrm{X}$ dari pada kromosom $\mathrm{Y}$, sehingga keturunan betina yang dihasilkan lebih banyak (Wolfner, 2009). Segregation distorter terdapat pada suatu lokus genetik yang dapat menyebabkan ketidaknormalan pemisahan kromosom pada individu jantan (Ellis dan Carney, 2010).

Menurut Wolfner (2009) menyatakan bahwa sedikitnya jumlah sperma Y disebabkan pada saat terjadi meiotic drive (penyimpangan pemisahan pada anafase II) sperma Y gagal berpisah. Hal ini juga didukung oleh Ellis dan Carney (2010) bahwa kromosom Y gagal berpisah selama meiosis dan gagal menuju kutub. Gagal berpisahnya kromosom Y dalam proses spermatogenesis, menyebabkan proporsi terbentuknya sperma Y menjadi sedikit. Perbandingan antara pemisahan kromosom X dan Y pada tahap anafase II yang normal dan tidak normal pada $D$. simulans dapat dilihat pada gambar 3 .

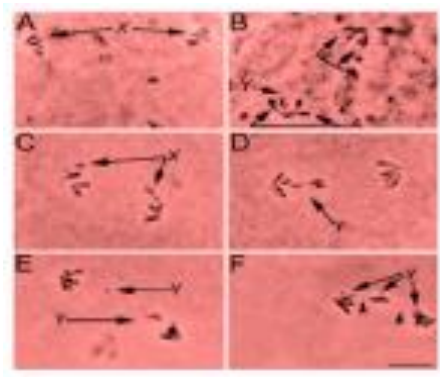

Gambar 3. Pewarnaan dengan acetolactic orcein pada tahap anafase II D. simulans jantan. (A) pemisahan normal kromosom $\mathrm{X}$ dan autosom. (B) pemisahan normal kromosom $\mathrm{Y}$ dan autosom. (C) pemisahan normal kromosom $\mathrm{X}$ dan autosom. (D-F) Pemisahan yang tidak normal pada kromosom Y. (D) Dua kromatid Y tidak berpisah ke kutub yang berlawanan. (E) Sebagian kecil kromosom Y menuju kutub yang berlawanan. (F) Serat kromatid tipis terlihat pada kromosom Y (Sumber: Cazemajor et al., 1997)

Sperma yang ditransfer individu jantan yang mengalami meiotic drive sebagian besar berupa sperma $\mathrm{X}$, sehingga sel telur lebih banyak dibuahi oleh sperma yang mengandung kromosom $X$. Hanya sebagian kecil sel telur yang dibuahi oleh sperma $Y$, karena diduga sperma $\mathrm{Y}$ gagal berkembang. Hasil penelitian Wolfner (2009) dengan menandai gen penyebab meiotic drive yaitu gen distorter, diketahui bahwa adanya gen distorter dapat meningkatkan frekuensi sperma $\mathrm{X}$ dibandingkan sperma Y. Dengan banyaknya proporsi sperma X, maka frekuensi untuk dihasilkan keturunan betina lebih besar. Dari penelitian Belloni et al., (2002) berdasarkan sitologinya diketahui dengan pewarnaan preparat pada bagian nukleus terjadi perubahan bentuk pada kromosom $\mathrm{Y}$ yang mengalami meiotic drive. Perubahan bentuk tersebut diduga disebabkan oleh kegagalan kromosom Y untuk berkembang.

Terkait karakterisitik spermatozoa $D$. melanogaster , karakteristik spermatozoa Y adalah bergerak cepat, sehingga jika lebih dahulu mengalami fertilisasi dengan sel telur akan dihasilkan keturunan jantan lebih banyak dibandingkan dengan keturunan betina. Namun demikian umur sperma Y lebih pendek dari pada sperma X (Corebima, 1997). Sehingga jenis kelamin keturunan yang lebih banyak dihasilkan adalah betina.

Berdasarkan hasil analisis statistik diketahui bahwa perbedaan umur betina berpengaruh nyata terhadap jumlah keturunan $D$. melanogaster pada persilangan sesama strain $n, t x$, dan se $(\mathrm{P}=0,00)<0,05$ pada taraf 5\%. Dari hasil uji lanjut BNT taraf 5\% diketahui bahwa umur betina 8-10 dengan umur betina 12-14 jam tidak berbeda nyata terkait dengan jumlah keturunan yang 
dihasilkan. Selain itu diketahui umur betina 8-10 jam dan umur betina 12-14 jam berbeda nyata pengaruhnya dengan umur betina 16-18 jam, 20-22 jam, dan 24-26 jam tetapi umur betina 16-18 jam berbeda nyata dengan umur betina yang lain. Untuk umur betina 20-22 jam dengan umur betina 24-26 jam diketahui bahwa tidak ada perbedaan yang nyata terkait jumlah keturunan yang dihasilkan.

Namun berdasarkan data yang diperoleh, diketahui bahwa umur betina 20-22 jam memberikan jumlah keturunan terbanyak sedangkan umur betina 8-10 jam memberikan jumlah keturunan paling sedikit. Hal ini artinya dalam persilangan $D$. melanogaster khususnya strain $n, t x$, dan se cukup baik dilakukan pada umur betina 20 26 jam untuk menghasilkan keturunan yang banyak. Umur betina 20 jam memberikan jumlah keturunan terbanyak dalam persilangan $D$. melanogaster sesama strain $n$, $t x$, dan $v g$ (Karmana, 2010). Terkait dengan umur kawin atau kedewasaan seksual $D$. melanogaster diperoleh informasi yang bervariasi. D. melanogaster betina mencapai kedewasaan seksual pada umur 8 jam setelah menetas dari pupa (Shorrock, 1972). D. melanogaster betina mencapai kedewasaan seksual pada umur 24 jam setelah menetas dari pupa (Hartanti, 1995). D. melanogaster betina mencapai kedewasaan seksual setelah umur 24 jam setelah menetas dari pupa (Fowler, 1973).

Berdasarkan hasil analisis statistik diketahui bahwa ada pengaruh interaksi strain dengan umur betina terhadap jumlah keturunan $D$. melanogaster pada persilangan menggunakan strain $N$, $t x$, dan se $(\mathrm{P}=0,001)<0,05$ pada taraf $5 \%$. Untuk persilangan sesama strain $n$ dengan umur betina 20-22 jam dan umur betina 24-26 jam menghasilkan rata-rata jumlah keturunan berturutturut sebesar 568,2 ekor dan 548,6 ekor, sedangkan persilangan sesama strain $n$ dengan umur betina 8 10 jam, 12-14 jam, dan 16-18 jam mengalami penurunan rata-rata jumlah keturunan berturut-turut sebesar 407,8 ekor; 438,6 ekor dan 519,8 ekor. Untuk persilangan sesama strain $t x$ dengan umur betina 20-22 jam dan umur betina 24-26 jam menghasilkan rata-rata jumlah keturunan berturutturut sebesar 429,6 ekor dan 417,4 ekor, sedangkan untuk persilangan sesama strain $t x$ dengan umur betina 8-10 jam, 12-14 jam, dan 16-18 jam mengalami penurunan rata-rata jumlah keturunan sebesar 378,8 ekor; 387,6 ekor dan 405,6 ekor. Untuk persilangan sesama strain se dengan umur betina 20-22 jam dan umur betina 24-26 jam menghasilkan rata-rata jumlah keturunan berturutturut sebesar 482,8 ekor dan 465,4 ekor, sedangkan persilangan sesama strain se dengan umur betina 810 jam, 12-14 jam, dan 16-18 jam mengalami penurunan rata-rata jumlah keturunan berturut-turut sebesar 385,4 ekor; 405,6 ekor dan 437,6 ekor. Dari ketiga tipe persilangan sesama strain $N$, tx dan se dengan umur betina 8-10 jam, 12-14 jam, 16-18 jam,
20-22 jam, dan 24-26 jam yang menghasilkan keturunan terbanyak adalah persilangan sesama strain $n$ dengan umur betina 20-22 jam dan 24-26 jam, sedangkan untuk persilangan sesama strain $t x$ dengan umur betina 8-10 jam dan 12-14 jam menghasilkan keturunan paling sedikit. Suatu strain D. melanogaster memiliki umur betina yang khusus untuk menghasilkan keturunan yang banyak (Karmana, 2010).

\section{PENUTUP}

\section{Kesimpulan}

Berdasarkan hasil penelitian yang diperoleh, membuktikan bahwa ada perbedaan strain dan umur betina terhadap jumlah keturunan lalat buah (D. melanogaster Meigen). Terkait umur betina yang paling banyak menghasilkan keturunan adalah umur 20-26 jam. Hasil penelitian ini memperkuat hasil penelitian sebelumnya mengenai umur betina yang paling tepat untuk berlangsungnya perkawinan. Oleh karena itu, untuk perkawinan $D$. melanogaster sebaiknya dilakukan pada umur betina 20-26 jam agar diperoleh jumlah keturunan yang banyak.

\section{REFERENSI}

Belloni, M., Tritto, P., Bozzetti, M., Palumbo, G. Robbins, L. 2002. Does Stellate Cause Meiotic Drive In Drosophila melanogaster. Genetics, 1551-1559.

Campbell, N.A., Recce, J.B., Mitchell, L.G. 2002. Biologi. Edisi Kelima Jilid 1. Terjemahan oleh R. Lestari. Erlangga: Jakarta

Cazemajor, M., Landre, C., Moreau, M. 1997. The Sex-Ratio Trait in Drosophila simulans: Genetic Abalysis of Distortion and Suppression. Genetics, 147:635-642.

Corebima, A.D. Genetika Mendel. 1992. FMIPA IKIP Malang: Malang

Corebima, A.D. 1997. Genetika Kelamin. Surabaya: Airlangga University Press.

Corebima, A.D. 1997. Genetika Mendel. Surabaya: Airlangga University Press

Fowler, G.L. 1973. Some Aspect of Reproductive Biology of Drosophila: Sperma Transfer, Sperma Storage, and Sperma Utilization. Genetics.

Haerty, W., Jagadeeshan, S. Rob J. Kulathinal, A. Wong, K. Ram, L. K. Sirot, L. Levesque, Evolution in the Fast Lane: Rapidly Evolving Sex-Related Genes in Drosophila,Genetics, 1321:1335, 2007.

Hanafiah, K.A. 2003. Rancangan Percobaan: Teori dan Aplikasi. PT Raja Grafindo Persada. 
Hartanti, S. 1998. Studi Kecepatan Kawin, Lama Kopulasi dan Jumlah Turunan Drosophila melanogaster Strain Black dan Sepia Pada Umur 2 dan 3 Hari. Skripsi. Malang: IKIP Malang.

Indayati, N. 1999. Pengaruh Umur Betina dan Macam Strain Jantan Terhadap Keberhasilan Kawin Kembali Individu Betina Drosophila melanogaster. Skripsi. IKIP Malang.

Karmana, I.W. Pengaruh Macam Strain dan Umur Betina Terhadap Jumlah Turunan Lalat Buah (Drsopohila melaonagster: Gane Swara, 4:1-6, 2010)

Lisa, L., Carney, E. Ginger. Socially-responsive Gene Expression in Male Drosophila melanogaster is Influenced by the Sex of the Interacting Partnerm. Genetics. 157:16, 2010.

Muliati, L. 2000. Pengaruh Strain dan Umur Jantan Terhadap Jumlah Turunan Jantan dan Betina Drosophila melanogaster. Skripsi. Malang: Fakultas-MIPA Universitas Negeri Malang Jurusan Biologi.

Oktarianti, R. dan Widajati, S. Petunjuk Praktikum Genetika. Laboratorium Zoologi Jurusan Biologi FMIPA Universitas Jember. 2011.

Shorrock. 1972. Drosophila. Gin and Company Limited.

Sirot, L.K., LaFlamme, B.A., Sitnik, J.L., Rubinstein, D., Avila, C., Chow, Wolfner, M. F. 2009. Molecular Social Interaction: Drosophila melanogaster Seminal Fluid Protein as a Case Study. Advanced in Genetics, 68:23-56.

Stansfield. 1991 Genetika Edisi Kedua. Jakarta: Erlangga.

Wilkinson, G. S., Sanchez, M.I. Sperm Development, Age and Sex Chromosome Meiotic Drive In The Stalk-eyed Fly. Cyrtodiopsis whitei. Heredity, 87:17-24, 2001.

Wolfner, M.F. 2009. Battle and Bellet: Molecular Interactions Between the Sexes In Drosophila. Journal of Heredity, 4:399-410.

Wong, A., Turchin, M. C., Wolfner, M.F., Aquadro, C.F. 2012. Temporally Variable Selection On Proteolysis-Related Reproductive Tract Proteins in Drosophila. Mol. Biol. 29(1):229-238. 